\title{
FGFR2 NP_000132.3:p.P253R
}

National Cancer Institute

\section{Source}

National Cancer Institute. FGFR2 NP 000132.3:p.P253R. NCI Thesaurus. Code C107591.

A change in the amino acid residue at position 253 in the fibroblast growth factor receptor 2 protein where proline has been replaced by arginine. 